$2 \mathrm{E}-09$

\title{
速度見越課題における眼の活動
}

\section{O田多英興, 吉田信西（東北学院大学教荃学部），大佐賀敦（東北大学医学部）}

\section{Eye Behaviors during the Speed Anticipation Task Performance}

Hideoki Tada, Shinya Yoshida (Dept. of Psychology, Faculty of Liberal Arts, Tohoku Gakuin Univ.), Atsushi Osaga (Tohoku Univ. Sch. of Med., Undergraduate Course)

\section{1 はじめに}

速度見越検査は運転手の適性検査として標準 的なものであるが、同時にヒトの遂行行動

(Performanice)の解析またはメカニズムの推定 をする上でも格好の素材である。特に、2 種の 代表的な眼球運動が盛り込まれていることは、 眼の行動（Eye Behavior）を考える上で非常に 好都合である。

\section{2 目的}

速度見越課題における反応を決定している要 素を推定するために、この事態における眼球運 動と瞬目のありさまをやや詳しく解析すること と、2 次的には性格特性との関倸を推定するた めにタイプA検査（山崎ら 1992）との関倸も検 討することが目的である。

\section{3 方法}

3-1 被験者：大学生 24 名（男子 11 名、女子 13 名、平均年齡 19.8 歳）。

3-2 課題 : 被験者は、ズレた文字の読みの課題

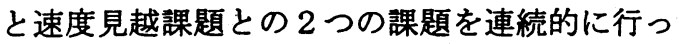
た。速度見越課題は市販の装置を、視角・音・ 時間などについて、出来るだけ忠実に C R T 上 に再現して実施した。

3-3 装置: ポリグラフシステム (NEC 三栄 360 システム), E E Gモニタリングシステム (NEC 三栄 EL1102）、刺激提示用モニターテレビ (SHARP CU-21HD) 、デジタルレコーダ （TEAC DR-M2a）、実験刺激制御にはパソコ ン（NEC PC9821 Ap2）のウィンドウズ環境を 用いた。

3-4 生理指標: 生理指標は、(1)瞬目（垂直眼球
運動：時定数 3.0 秒)、(2)水平眼球運動（時定数 10 秒、一部は直流)、(3)指尖容積脈波（時定数 0.1 秒)、そして呼吸（時定数 3.0 秒）などであ った。水平垂直の眼球運動の記録は眼の上下と 外角に銀塩化銀電極を装着する通常の方法で記 録した。指尖容積脈波は三栄制の光電式のピッ クアップ、呼吸は腹式ピックアップによる。

3-5 手続き: 電極をつけ終わると高さの調節の 出来る床屋椅子に誘導して、一定の様式にした がって課題の教示を行う。後に理解の届かなか った部分だけをあらためて説明し、実験にはい った。刺激の提示はすべてパソコンで完全に自 動的に制御・実行された。所要時間は被験者に よって異なるが、約 20 分前後である。

\section{4 結果}

4-1 速度見越反応: 見越反応時間は平均 $2740 \mathrm{~ms}$ 、標準偏差 $716.8 \mathrm{~ms}$ で、ほぼ正規分布に 近い分布を示したが、通常の見越時間（丸山ら、 1995, P43）よりはかなり延長している傾向がう かがわれた。それが何に起因するかの詳細は分 からないが、(1)眼電図などの電極をつけたこと、 (2) C R Tディスプレーにしたこと、などがその 原因と考えれらるが、しかし一方では前回の今 回とほぼ同じ内容の実験（Tada，1978）でもほ ぼ同じ結果を得ていることを考えると、(1)の要 因が有力である。また、試行間の反応時間は、 試行の進むにつれてやや增加する傾向が見られ た。このように、以下、やや延長気味の見越時 間の被験者によるデータの解析の結果である。

4-2 眼球運動と速度見越反応: 速度見越課題に は4つの相（Segments）があるが、(1)用意 
（Warning：約 5.4 秒）、(2)追従（眼球運動）相 (Pursuit：約 2.1 秒)、(3)飛越（眼球運動）相 (Saccade : 可変)、(4)試行間間隔（Inter Task Interval : 約 13.6 秒) である。本研究では特に (2)と(3)とに注目した。

まず、飛越相における飛越の回数と見越反応 時間の関係を見ると図 1 のようになる。両者は 非常に高い相関（r=.691, P<.0002）があり、見 越時間においてやや延長気味の被験者の資料で はあるが、以前の結果（Tada, 1978）を確認す るものであった。つまり、飛越眼球運動を丁寧 にするほど見越時間は延長する傾向があり、飛 越を省略することが相対的ながらいわば尚 早」反応に結びつくことが示唆される。

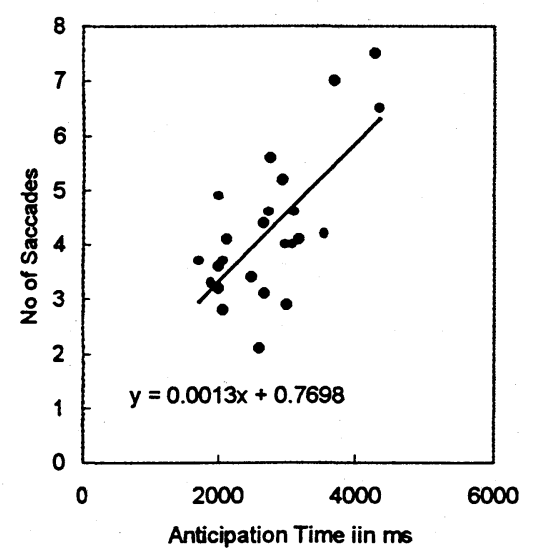

Fig. 1. Anticipation times as a function of saccades.

\section{4-3 飛越眼球運動と瞬目率との関係: 以前の研究}

（Tada, 1978）では、見越反応のやや速めの人た ちは瞬目も多いことが示唆されたので、今回もこの 解析を行ったが、予想に反して今回は全く相関が認 められなかった（r=.0897, n.s.）。

4-4 速度見越反応事態における瞬目活動：

(1)瞬目率：速度見越課題の各相における瞬目率を 記録すると図 4 のようになる。追従相における光点 が出現するまでの「用意」の時問はほぼ平均的な定 常状態の瞬目率であり、追従相に入るとと同時に瞬
目はほとんど完全に抑制され、飛越眼球運動の相ま でそれが続く。通常はこの問はほとんど瞬目はゼロ （15人）であるが、中にはこの問にも眼球が多少 なりとも動いた被験者がいた（9人：必ずしも同し 人ではない)。そして、キー押しを終わると同時に バースト上に瞬目が出現する。

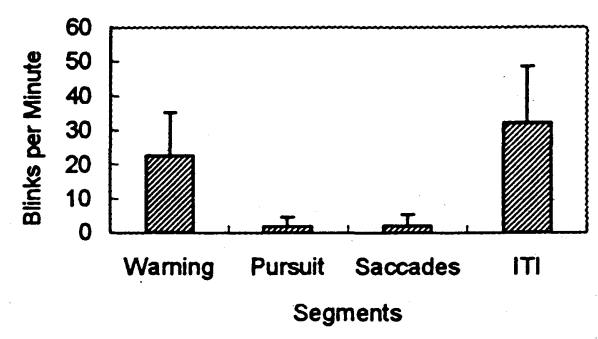

Fig. 2. Eye blink rates as a function of segments.

(2)瞬目波形：波形分析のアルゴリズムは本大会の 別の部門で報告した（大佐賀ら、1994）。その方 法に従って分析した波形の属性は、振幅、持続時間 (100\%)，持続時間 $(50 \%)$ 、左の傾き、右の傾 き、面積の 6 種である。そうやって得られた資料に ついて、上記の 4 つの相ごとにどんな差があるかを、 性×相の分散分析で解析した結果、相条件の主効果 には有意差がなく、性の主効果で有意な差が得られ たのが、100\%持続時間（F(1/57)=4.99, $\mathrm{P}=.029 ）$ 、 傾向が見られたのが、振幅 $(\mathrm{F}(1 / 57)=3.29, \mathrm{P}=.075)$ 、

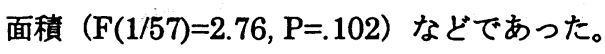

4-5タイプA特性とその他の指標との関係: 実 験後に各被験者にタイプA検查を実施した。タ イプAの 4 つの尺度 (A、AH, H T, S P) 得点と本実験で行ったいくつかの指標（飛越眼 球運動一順行と逆行一、いくつかの時点の瞬目、 瞬目の変化率など）との相関を検討したが、有 意な相関が見られた項目はなかった。

4-6 各指標間の相関関倸: 上記の眼球運動およ び瞬目の諸指標間の相関を見ると、(1)通常は見 られない追従相での飛越運動が見られたこと、 (2)追従相でも飛越相でも逆行飛越眼球運動が見 られた、それらがそれぞれ特異な（相関）関倸 を示した。 